\title{
Analysis of tourism supply of the city of Zagreb and perspectives of its future development
}

\author{
Milena Podovac $^{1 *}$, Danijel Drpić ${ }^{2}$ Vedran Milojica ${ }^{3}$ \\ ${ }^{1}$ University of Kragujevac, Faculty of Hotel Management and Tourism in Vrnjačka Banja, \\ Serbia \\ ${ }^{2}$ Polytechnic University in Rijeka, Croatia \\ ${ }^{3} \mathrm{PhD}$ student, University of Rijeka, Faculty of Tourism and Hospitality Management \\ Opatija, Croatia
}

\begin{abstract}
The specificity of city tourism is reflected in the fact that this form of tourist product enables meeting the needs of tourists with different characteristics, needs and motives by combining exis ting tourismres ources and contents into the city touris m supply. Being the capital of the Republic of Croatia, Zagreb is a significant tourist destination, which has the potential for city touris mdevelopment with the aim of improving the competitiveness of this destination in the tourismmarket. In this paper, the authors performed an analys is of theoretical knowledge about the concept, significance and characteristics of city tourism, an analys is of current touris m supply of the city of Zagreb and of quantitative indicators of tourism development in this city. Based on the analysis of tourism supply, strategic guidelines forimproving the development of city touris $m$ in the city of Zagreb have been defined.
\end{abstract}

Keywords: city touris m, city, city of Zagreb, competitiveness, tourist destination JEL classification: L83, M21

\section{Analiza turističke ponude grada Zagreba i perspektive budućeg razvoja}

Sažetak: Specifičnost gradskog turizma ogleda se u činjenici da ovaj oblik turističkog proizvoda omogućava zadovoljenje potreba turis ta različitih obeležja, potreba i motiva kombinovanjempostojećih turis tičkih resursa i sadržaja u ponudu gradskog turizma. Kao glavni grad Republike Hrvatske, Zagreb predstavlja značajnu turističku destinaciju koja poseduje potencijal za razvoj grads kog turizma sa ciljem unapređenja konkurentnosti ove destinacije na turističkom tržištu. U radu je izvršena analiza teorijskih saznanja o pojmu, značaju i karakteristikama gradskog turizma, analiza postojeće turističke ponude grada Zagreba, kao i kvantitativnih pokazatelja razvoja turizma u ovom gradu. Na os novu analize turis tičke ponude, definis ane su strateške s mernice za unapređenje razvoja gradskog turizma u gradu Zagrebu.

Ključne reči: gradski turizam, grad, grad Zagreb, konkurentnost, turistička destinacija JEL klasifikacija: L83, M21

* milena.podovac@kg.ac.rs 


\section{Introduction}

City tourism is an innovative touris mproduct which utilizes the existing tourism resource for creating new tourismsupply with the aim to provide a competitive position in the touris $m$ market for the cities. For certain cities, tourism represents a significant novelty after great changes in the economic and social system of the city. For the last few years, touris $m$ has represented an activity contributing to the development of the total service sector bearing in mind a stable influx of touris ts in the cities throughout the whole year (Smolčić-Jurdana \& Magaš, 2006).

The significance of cities as tourist destinations reflects their multi-functional character, specifically their capability to satisfy various needs, motives and preferences of tourists. Cities attract a large number of people whocome to vis it their relatives and friends. Besides that, cities are attractive destinations for those tou rists attracted by v arious types of event and attractions which are notrepresented in other destinations. This advantage is used by the city's destination management with a goal of improving tourism supply through the introduction of new facilities and attractions (Smolčić-Jurdana, as cited in Ivanović et al., 2015). "In addition to meeting the needs of different segments of tourists, cities as tourist destinations are made up of a large number of elements, each representing an individual touris m product" (Kolb, 2006, p. 5).

The city of Zagreb posses ses a significant potential for achieving a more competitive city touris m supply. The basis of the development of Zagreb city tourism supply includes natural and anthropogenic resources, developed accommodation supply, a large number of tourist events and other facilities. In order for the city of Zagreb to achieve and maintain a competitive position in the development of city tourism, it is necessary to undertake constant adaptation of its tourism supply according to the needs of contemporary tourists who expect greater value in relation to the price they are paying for their travel. Also, the success of Zagreb as a destination of city tourismdepends on monitoring trends in the development of this touris mformin the European and world capitals and applying best practices with the goal of improving the current tourism supply. The success of the city of Zagreb in the development of its tourism supply can contribute towards achieving competitiveness of total tourism industry of the Republic of Croatia. The goal of this paper is to represent the theoretical characteris tics of city tourismas well as the analysis of current touris m supply of Zagreb and determining the perspective of future development of its tourism supply. In this paper, authors analy zed touris ms upply of the capital city of the Republic of Croatia, the city of Zagreb. Based on the determined findings, the guidelines for touris ms upply improvement are proposed.

\section{City tourism as an element of a contemporary destination's supply}

Over the years, contemporary tourism has been registering significant changes within its structure; although Bathing tourism (clas sical 3S-Sun, Sea and Sand supply) is still holding a strong place in today's tourismflows, specific forms of tourism are on the rise (Alkier et al., 2009; Ivanović et al., 2016a), and city tourismis most definitely one of them. Valls et al. (as cited in Pasquinelli \& Bellini, 2017) confirm that in their research by stating that the holidays spent in the seaside that started registering strong growth in the 1960s started slowly decreasing and city tourisms tarted growing. All this occurred as a result of the improvement of connectedness between European cities due to the liberalization of air trans portation in the European Union which had both quantitative and qualitative impact on travelers' flows. Due to the low-costcarriers as a much cheaperway of travel, tourists were able to start visiting various destinations in a much affordable way. It can be assumed that this was one of the 
reasons that enabled them to start traveling more frequently on multiple shorter holidays throughout the year.

Although it has developed massively in the last decades of the 20th century, city tourism is not a new phenomenon (Stanić Jovanović, 2016). Law (2002) emphasizes that city tourism was significantly neglected in the past research due to the fact that the primary focus was made on Bathing touris m and the development of coastal destinations. Also, researchers were experiencing problems in discerning tourists from the local inhabitants in order to estimate the significance of tourismfor city development. According to Štetić et al. (2014), "significant attention was given to the development of city tourismby the city managers and marketing experts during the eighties of the twentieth century when grand industrial cities started declining" (p. 145). City touris mis based on their economic functions by which the significance of the business sector, grand exhibition and fair capacities, transport connections, etc. is emphasized. In the meantime, an evolution development of the cities occurred, as well as changes in managing the space within them, which resulted in redefinition of the significance of tourism for the cities' development. It also resulted in regeneration and redesigning of old city cores, neighborhoods, and abandoned industrial zones, all with a goal of attracting investors who will build establishments and facilities intended for tourists. Podovac (2019) states that cities are multi-functional destinations in which tourists can satisfy a greater number of touristneeds, and various touris $m$ forms that occur in cities can be included in city tourism supply. City tourism has become a complex object of scientific and professional research for some years now, which has made a significant contribution towards further improvements of city touris m supply aiming it improving the tourisms upply of an entire region or even a country. The following authors present the most recent findings in the area of city tourism. Ivanović et al. (2015) emphasize the role of city touris mas a specific form of touris $m$ whose particularities contribute to the achievement of destination's competitiveness in the tourismmarket and successful pla cing of des tinations supply in the international tourismmarket. The demand for city tourismproduct is registering a continuous growth on daily basis. This is conditioned by destinations possessing specific tourismres ources which enable tourisms upply creators to form a unique touris m supply which will contribute in achieving city's and the state's recognizability on in the international tourist tourismmarket, as well as forming a recognizable image and brand which guarantees vis itors recurring aualitv. and experiencing value and experience for the money. All this will enable success ful competition in the international tourism market.

Bearing in mind the importance of city brand development, Folg ado-Fernandez et al. (2015) researched the extent of contribution of cultural heritage, events, tourist attractions, and infrastructure in developing brand images of cities. The research results show how these resources contribute significantly, but also at the same time differently in forming city brand image. The results have provided destination managers new insights on how to use each resource in the best possible way to develop a strong city brand as well as how to improve their marketing activities and strategies for their cities. Galdini (2007) analyzed on the example of the city of Genoa how undertaken investments in urban regeneration can result in new positive economic effects, as well as in improving the quality of life of local residents. She attempted to examine both the benefits and the costs that tourism has on host's environment, economies and the societies. Based on the findings, she analyzed the strategic conditions that can contribute towards revitalizing the territory. On the example of Genoa she showed how the city regained a new identity and role in the Italian economic and social system after the crisis. Tokarchuk et al. (2016) focused on determining the effect of city touris mon the well-being of urban residents by analyzing the effects of tourist nights spent in the centers of cultural tourism on and life satisfaction of city residents. Besides a significant theoretical contribution, the results of empirical research enabled the authors to 
propose appropriate policy implications with a goal of contributing towards further development of city tourism as well as improving life quality of local residents.

As can be seen from the above, various researches have undertaken research in city touris $m$, and one thing can be distinguished as common to all of them: they are all aimed towards determining ways and possibilities of improving the current state of city touris m supply and rethinking new directions of the development of new elements of tourism supply. Podovac (2019) emphasizes in her work that "the tourism development has been recognized and us ed as the means of economic growth and city development, which als o contributes signific antly towards the increase of employment and improvement of life quality of the local population" (p. 29). Tourism development in cities influences all segments of city functioning due to which complex relations between tourism and other forms of economic activities are established on the city level. Besides that, tourism influences the city's cultural and social development as well, in the sense of tourists being able to get introduced with the destination's culture and tradition, language, gastronomic delicacies, and other things. The advantages are multiple. However, in order to be able to develop a successful and competitive city tourism supply, tourism supply developers need to pay particular attention to adapting to the contemporary market trends while at the same time making an effort in preserving a city's own authenticity and tradition which separates a certain city as a tourist destination on the tourist market.

\section{The analysis of the city of Zagreb tourism supply}

The city of Zagreb is the capital of the Republic of Croatia, and an attractive destination in which tourism is one of the leading economic activities. Zagreb is situated between the mountain Medvednica and the river Sava covering the surface of about $641 \mathrm{~km}^{2}$. The total population of the city of Zagreb amounts to approximately 790,011 , specifically $18.5 \%$ of the total number of inhabitants of the Republic of Croatia (City of Zagreb, City Office for the Strategic Planning and Development of the City, Department of Statistics ,2020). As an economic, political and cultural center of the Republic of Croatia, the city of Zagreb is extremely important for the total development of the country.

The city of Zagreb bases its tourism supply on the richness of natural and anthropogenic resources, developed accommodation, significant number of events and other facilities intended for tourists. Zagreb possesses significant natural resources that are suitable for touris m development. Considering its position in between Northern and central Croatia, more precisely in between county of Zagreb and county of Krapina-Zagorje, its geographical position is extremely suitable. Climate characteristics are largely dependent on the relief, altitude and other factors. Zagreb is characterized by a moderate continental climate with moderate temperatures during summer and winter (City Office for Economy, Energetics and Environment protection, 2015). Significant tourist attractions are represented by park surfaces of the city of which it is necessary to point out the Botanical garden, Maks imir Park, the ZOO of the city of Zagreb, etc. Natural land scapes of the city of Zagreb are characterized also by the large number of viewpoints which enable a complete experience for tourists Lotrščak Tower, Sljeme, etc.) (Official website of Tourist Board of the city of Zagreb, 2020b).

The city of Zagreb is a very important hub of European traffic corridors which pass throughout the city (Official website of City of Zagreb, 2011). In the city of Zagreb, all forms of trans port have been developed, except water transport due to the lack of navigable water surfaces (Department of Spatial Planning of the city of Zagreb, 2013). Zagreb is the hub for European transport corridors. Road and railway corridors pass through Zagreb: X (Salzburg - Ljubljana - Zagreb - Belgrade - Thessaloniki) and Vb (Rijeka - Zagreb - 
Budapest) (Official website of City of Zagreb, 2017). In the Republic of Croatia, railways are divided into those of great significance for international traffic, then for regional and local traffic. In the city of Zagreb, the railway traffic is organized in a way that all transit trains pass through the main station which is the starting and final one for all the local trains. The total length of corridor of railways is $141.13 \mathrm{~km}$, of which $137.37 \mathrm{~km}$ are the main ones (Department of Spatial Planning of the city of Zagreb, 2013). Public transport in the city of Zagreb consis ts of streetcar, bus and railway transport, lifts, and cable cars. The length of the streetcar network amounts to 58 kilometres of two-track railways on which 19 trans port lines are realized per day. The main problemof the development of streetcar traffic lies in the fact that approximately $40 \%$ of the rails is not physically separated from the individual traffic, due to which the speed and accuracy depend on the density of the same (Official website of City of Zagreb, 2017). Air traffic is exceptionally significant for tourism development of Zagreb. The carrier of development of air-traffic is the Airport Franjo Tuđman. In the year 2019 , a total of $3,435,531$ passengers were transported, which is a $3 \%$ increase in relation to the previous year. Also, 45,061 flights were made in 2019, which also registers a $3 \%$ increase in relation to the previous year. Airport Franjo Tuđman is connected with flights with 46 destinations, while in the regular air traffic flights are being done by 30 airlines (Franjo Tuđman Airport, Zagreb, 2019).

Besides the natural ones, the tourism supply of the city of Zagreb consists also from anthropogenic resources, of which it is necessary to emphasize the localities of culturalhistorical heritage, notably sacral buildings (Church of St. Mark from the thirteenth century, Zagreb Cathedral dedicated to the Assumption of the Holy Virgin Mary, etc.), squares (Ban Josip Jelačić Square, Nikola Šubić Zrinski Square, the Square of the Republic of Croatia, etc.), architectural buildings (the Croatian National Theatre, the Croatian State Archives). A large number of cultural institutions participates in touris m development of the city of Zagreb by organizing events, concerts, exhibitions and other cultural contents (city theatres, galleries, archaeological museum, the Croatian Historical Museum, the Museum of Contemporary Arts, etc., the Croatian Music Institute, the City Library) (Official website of Tourist Board of the city of Zagreb, 2020a).

Table 1: A review of the number of beds* in the city of Zagreb in the period 2015-2019

\begin{tabular}{|l|c|c|c|c|c|c|}
\hline Category & $\mathbf{2 0 1 5}$ & $\mathbf{2 0 1 6}$ & $\mathbf{2 0 1 7}$ & $\mathbf{2 0 1 8}$ & $\mathbf{2 0 1 9}$ & $\mathbf{2 0 1 9 / 2 0 1 5}$ \\
\hline $\begin{array}{l}\text { Hotels and similar } \\
\text { accommodation** }\end{array}$ & 7,464 & 7,672 & 7,849 & 7,787 & 8,768 & $+17.47 \%$ \\
\hline Hotels & 7,365 & 7,087 & 7,253 & 6,632 & 7,738 & $+10.02 \%$ \\
\hline $\begin{array}{l}\text { Rooms for rent, } \\
\text { apartments, studio } \\
\text { apartments, holidays } \\
\text { homes } * * *\end{array}$ & 889 & 4,472 & 5,924 & 10,588 & 8,586 & $+865.8 \%$ \\
\hline Hos tels & 2,304 & 2,165 & 2,286 & 2,346 & 2,197 & -4.65 \\
\hline Camp sites & - & - & - & - & - & - \\
\hline $\begin{array}{l}\text { Other accommodation } \\
\text { facilities**** }\end{array}$ & 4,062 & 800 & - & - & - & - \\
\hline Total & $\mathbf{1 4 , 7 1 9}$ & $\mathbf{1 5 , 1 0 9}$ & $\mathbf{1 6 , 0 5 9}$ & $\mathbf{2 0 , 7 2 1}$ & $\mathbf{1 9 , 5 5 1}$ & $+\mathbf{3 2 . 8 3 \%}$ \\
\hline
\end{tabular}

* Permanently available and extra beds

** Hotels, all-suite aparthotels, integral hotels, heritage hotels and special standard hotels *** Rooms for rent, apartments, studio apartments, holiday homes in households and rural households

**** Overnight accommodation, inns offering accommodation services, mountain huts Source: Official website of City of Zagreb (n.d.; 2020) 
The data in Table 1 presents the number of beds in the city of Zagreb in the period from 2015 to 2019. In this period, the total number of beds registered a growth of $32.83 \%$, within which the highest growth was registered for private accommodation $(+765.80 \%)$. Numbers of beds in hostels registered a decrease (-4.65\%). (Authors' calculation according to: Official website of city of Zagreb, 2020). Catering supply of Zagreb includes facilities that provide services of preparation and serving food and beverages, as well as entertainment facilities (restaurants, clubs, jazz clubs, wine cellars, beerhouses, casinos, cocktail bars, etc.). The supply also includes a large number of shopping malls, sports and recreation facilities, wellnes s centers and other facilities (Official website of Tourist Board of the city of Zagreb, $2020 \mathrm{~b}$ ), which allows for tourists to spend quality time while staying in this destination.

\section{Specific forms of touris $m$ in the city of Zagreb}

Special forms of tourism have been developed in Zagreb, such as cultural touris m, event touris m, business tourism and city touris m (city vacations) (Horwath HTL, 2011). Its rich cultural-his torical heritage represents the basis for the development of cultural touris mas one of the most significant tourism products for this destination. There are 619 immovable cultural goods, as well as 294 movable cultural goods and intangible cultural heritage registered in the city of Zagreb that are entered in the Register of Cultural Properties of the Republic of Croatia (Official website of City of Zagreb, 2017). Although it is one of the primary forms of touris min Zagreb, the further development of cultural touris $m$ will depend on continuous improvement of supply in the form of new cultural attractions, innovative facilities and cultural events, as well as maintaining the existing cultural infrastructure and adequate promotion policy.

Event touris msupply of the city of Zagreb is based on theatre shows, concert and musical events, exhibitions, fairs and congresses, cultural and traditional, as well as sports and other types of events. The events are organized continuously throughout the entire year, and their diversity and uniqueness is capable of satisfying everyone's taste. Manifestations held in Zagreb can be divided into three levels of attractiveness: international (the Zagreb Time Machine within which it is possible to see Dance Evenings - Zrinjevac, Upper Town in the Past, Promenade concerts, Folklore Performances, etc., Animafest, European University Games, International fes tival of Puppet Theatre, Zagreb Film Festival, etc.), regional (Zagreb Car Show,Zagreb Marathon, Floraart, Vintage Festival, etc.) and local (Night of Museums, folklore festival, St. Marks'festival, Summer nights of EXIT Theatre, Amadeo festival, etc.) (Horwath HTL, 2016; Official website of TouristBoard of the city of Zagreb, 2020a). One of the events that has significantly contributed to the event touris m development as a part of city touris mof the city of Zagreb is most definitely the Advent in Zagreb. This event has been organized since 2010 until today and every year registers further growth and development which has resulted in it becoming a recognizable brand, all a result of strong and significant efforts made by the municipal authorities and offices, Concert Direction of Zagreb and the Tourist Board of Zagreb. During the Advent, visitors can experience numerous everyday activities and manifestations create a unique picture of the main city during the holidays. All this is accompanied by intensive marketing activities (Ivanović et al., 2016b).

Business tourismis also successfully developing in Zagreb due to the existence of a large number of accommodation capacities which possess adequate buildings and appropriate infrastructure for the org anization of congres ses and various forms of meetings, as well as congress centers and halls. Good traffic connection with the other countries on the European continent, stabile economic situation, development of scientific-research activity can be identified as non-tourist reasons for expansion of this tourismform. According to the data of 
(International Congress and Convention Association, 2019) for the year 2018, Zagreb took $68^{\text {th }}$ place with 41 held business events in the range with 465 cities on the international le vel. If taken into consideration that Croatia is ranked as $38^{\text {th }}$ country on the world level with 108 held business events, it can be concluded that Zagreb is one of the most significant destinations for organizing business events on a country level. According to the data about the number of held business meetings on the European level for the year 2018, Zagreb is placed on the $36^{\text {th }}$ place ranged with 200 cities (International Congress and Convention Association, 2019).

Business and other events in Zagreb are organized in halls of significant cultural-his torical institutions such as museums, concert halls and galleries which possess the appropriate infrastructure for their realization. The most significant buildings for this formof tourism are congress centers and halls of which 4 centers with 36 halls are pointed out, whosecapacity is up to 1,200 places. An important pre-condition for the development of Business Tourism of the city of Zagreb is the existence of appropriate accommodation supply which is characterized by a growing number of 4 and 5 star hotels, which possess capacities for organization of business and other types of events (Business touris m, 2020).

The city of Zagreb has been recognized in the tourism market as a city touris $m$ destination. Factors that have brought to the development of city tourismin Zagreb primarily relate to the structure of resources which is made of attractions of anthropogenic character in the form of larger number of cultural sites, quality traffic infrastructure in terms of development of air traffic, diverse accommodation supply as well as additional facilities for rest and recreation in the destination. Besides that, the appearance of low-tariff airlines as well as a growing number of hotels in the total accommodation supply point to the creation of conditions for being visited by tourists who havelower or medium income, as well as younger touris ts. In 2019, in the city of Zagreb 83\% (Authors' calculation according to: Official website of City of Zagreb, 2020) of tourist visits were made by foreign ones, which speaks in favor to the fact that this city is recognized as a city tourism destination. To the image of Zagreb as a destination of city tourism contributes the fact that it is the capital city of an EU member, which points to its economic, social and political stability.

Table 2: Tourist arrivals in the city of Zagreb in the period 2015-2019

\begin{tabular}{|c|c|c|c|c|c|c|}
\hline \multicolumn{4}{|c|}{ Tourist arrivals } & \multicolumn{3}{c|}{ Tourist overnights } \\
\hline Year & Foreign & Domestic & Total & Foreign & Domestic & Total \\
\hline $\mathbf{2 0 1 5}$ & 859,140 & 218,638 & $\mathbf{1 , 0 7 7 , 7 7 8}$ & $1,428,551$ & 375,739 & $\mathbf{1 , 8 0 4 , 2 9 0}$ \\
\hline $\mathbf{2 0 1 6}$ & 920,303 & 232,295 & $\mathbf{1 , 1 5 2 , 5 9 8}$ & $1,620,899$ & 395,208 & $\mathbf{2 , 0 1 6 , 1 0 7}$ \\
\hline $\mathbf{2 0 1 7}$ & $1,082,222$ & 203,865 & $\mathbf{1 , 2 8 6 , 0 8 7}$ & $1,901,153$ & 362,605 & $\mathbf{2 , 2 6 3 , 7 5 8}$ \\
\hline $\mathbf{2 0 1 8}$ & $1,177,014$ & 223,187 & $\mathbf{1 , 4 0 0 , 2 0 1}$ & $2,101,705$ & 410,112 & $\mathbf{2 , 5 1 1 , 8 1 7}$ \\
\hline $\mathbf{2 0 1 9}$ & $1,210,921$ & 243,098 & $\mathbf{1 , 4 5 4 , 0 1 9}$ & $2,186,449$ & 452,513 & $\mathbf{2 , 6 3 8 , 9 6 2}$ \\
\hline
\end{tabular}

Source: Official website of City of Zagreb (n.d.; 2020)

Table 2 presents the data about the tourist turnover achieved in the city of Zagreb in the period 2015-2019. The data in the previous table indicates a positive trend of growth both for total achieved tourist arrivals and achieved touris tovernights. In the period 2015-2019 tounist arrivals regis tered a $34.91 \%$ growth, and touris tovernights growth of $46.26 \%$. The majority of arrivals and overnight stays were made by foreign tourists (Authors'calculation according to: Official website of City of Zagreb, 2020). 
During 2017/18, an empirical research was made with a goal of determining the profile of touris ts who stay in the city of Zagreb as well as the characteristics of their stay and way of spending their time in the destination. The results of the research that was conducted on the sample of 2,007 touris ts have shown that tourists who visit Zagreb mostly belong to the age group 26-35 (31\%). The majority of visitors have a university degree, as well as an average monthly income $€ 2,385$. Of the total number, $32 \%$ of the touris ts prefer traveling with their spouse or a partner, $31 \%$ alone and $26 \%$ with their friends. When choosing their accommodation, $64 \%$ of touris ts indicate that they prefer staying in a hotel $\left(82 \%\right.$ in a $3^{*}$ and $4 *$ hotels). In terms of activities during their stay, $88 \%$ of touris ts visited Ban Jelačić Square, $71 \%$ spent time in coffee shops and cafes, $21 \%$ vis ited the Museum of Broken relationships, $18 \%$ visited the Botanical Garden, $11 \%$ the Maksimir Park Zoo, 7\% the Medvedgrad Fortres s, $6 \%$ the Jarun Lake, $4 \%$ the outskirts of Zagreb. It is very important to mention that $93 \%$ of tourists attended the Advent in Zagreb (average 2 visits), and $73 \%$ stated that Advent would encourage them to re-visit Zagreb (Official website of Tourist Board of the city of Zagreb, 2018). Based on the previously presented findings, in the following section, the authors will present the strategic guidelines which are aimed towards the improvement of touris m supply of the city of Zagreb.

\section{Strategic guidelines for the improvement of city tourism supply of Zagreb}

Based on the previous research results, the authors present the following strategic guidelines:

- Considering the possibilities for applying the concept of smart development with the aim of improving the city tourisms upply of the city of Zagreb based on smart technologies. The benefits that can be achieved by using s mart technologies include better quality of city tourism supply for tourists as well as a more efficient business performance of touris $m$ and hotel companies in the city of Zagreb;

- Enabling permanenteducation foremployees in tourismand hotel companies in order to raise the quality of services to a higher level and satisfy the tourist needs, which will further influence a better positioning of the city of Zagreb in the tourism market;

- Intensive cooperation of subjects frompublic and private sector in order for city touris $m$ to become a recognizable and contribute to a better competitive position on the touris $m$ market;

- Organization of a larger number of tourist events with special emphasis on cultural events in order to increase a total tourist turnover of the city of Zagreb throughout the entire year;

- Harmonization of city tourismsupply with the needs of modern touris ts, which will be based on monitoring and implementation of best practices of competitive European cities while preserving its authenticity at the same time;

- Improving the quality of the supply in hotels by providing additional facilities for touris ts (s ports and recreational facilities, spa \& wellness services, event organization, quality gas tronomic supply, children's facilities, etc.);

- Improving the quality of the accommodation supply through build ing new hotel facilities in the center of the city of Zagreb as well as nearby tourist attractions and the airport;

- Ensuring additional financial funds for preserving, arrangement and improving the quality of the city's infrastructure;

- Strengthening interconnections among all interested stakeholders in the tourism supply of the city of Zagreb;

- Improving knowledge and skills in managing structures of the city and city's Tourist Board; 
- Creating synergy among ins titutions in culture, religious ins titutions and tourist economy of the city of Zagreb;

- Forming a strategy for the development of city tourism of Zagreb;

- Harmonization of city developmental strategies with those on a higher level;

- Creating and conducting programs of financing touris mdevelopment through the use of EU funds;

- Ensuring the permanent safety of all stakeholders in the tourism process;

- Guiding towards target market niches;

- Establis hing cooperation with other main cities in Europe, forming joint tourist products and tours;

- Value for money of touris m products and services;

- Improving the existing marketing and promotion mix;

- Forming recognizable brands of the city and guiding activities towards increasing the competitive advantages.

Through the implementation of previously presented guidelines, it is expected that the city of Zagreb will achieve an increase of its competitiveness on the tourist market, and especially in the field of city tourism supply.

\section{Conclusion}

Contemporary trends on the tourist market indicate a growing significance of city tourism and its role in creating a unique city's supply which enables an influx of touris ts throughout the year. Des pite possessing significant tourist potentials, the city of Zagreb still has not reached a maximum level of the development of its tourism supply. One of the key preconditions for reaching it is the adaptation of tourism supply to the needs of contemporary city tourists. Besides that, competitive positioning on the tourist market depends on tracking the developmental model of city tourismin the cities which represent the examples of good practice. Based on the conducted analys is of the existing touris m supply in this paper, the authors have defined strategic guidelines that could improve the development of city touris $m$ supply of Zagreb.

\section{References}

1. Alkier Radnić, R., Gračan, D., \& Milojica, V. (2009). Tourism features within the European Union with special attention paid to Croatia. In V. Kandžija and A. Kumar (Ed.). 7th International Conference Economic Integrations, Competition and Cooperation (pp. 1-14). Rijeka, Croatia: Faculty of Economics, University in Rijeka.

2. Business tourism. (2020). Zagreb. Retrieved March 11, 2020 from https://www.pos lovniturizam.com/destinacije/zagreb/17/

3. City of Zagreb, City Office for the Strategic Planning and Development of the City, Department of Statistics. (2020). Osnovnipodaci o gradu Zagrebu. [Basic information about the city of Zagreb]. Retrieved March 7, 2020 from http://www1.zagreb.hr/zgstat/index.html

4. City Office for Economy, Energetics and Environment protection. (2015). Nacrt Programa zaštite okoliša grada Zagreba-nacrt [Environmental Program of the City of Zagreb - draft version]. Retrieved March 6, 2020 from https://eko.zagreb.hr/UserDocsImages/arhiva/dokumenti/Okoli\%C5\%A1/Otpad/PZO/PZ O_Grad_Zagreb_\%2021.1.2015.pdf

5. Department of Spatial Planning of the city of Zagreb. (2013). Izvješće o stanju u prostoru grada Zagreba 2008-2012. [Space Report of city of Zagreb 2008-2012]. 
Podovac, M. et al. - Analysis of tourism supply of the city of Zagreb and perspectives of its future development Hotel and Tourism Management, 2020, Vol. 8, No. 1: 89-99.

$\begin{array}{llll}\text { Retrieved } & \text { May } & 5, & 2020\end{array}$ http://www1.zagreb.hr/zagreb/slglasnik.nsf/7ffe63e8e69827b5c1257e1900276647/6bf3c 0c1ad894a57c1257c35005512c2/\$FILE/Izvje\%C5\%A1\%C4\%87e\%20o\%20stanju\%20u \%20prostoru\%20Grada\%20Zagreba\%202008-2012.pdf

6. Folgado-Fernandez, J. A., Olivieira Duarte, P. A., \& Hernandez Mogollon, J. M. (2015). As sessing the differentiated contribution of city res ources to city brand image. Tourism and Management Studies, 11(1), 77-83.

7. Franjo Tuđman Airport, Zagreb.(2019). Statistics at Franjo Tuđman Airport. Retrieved March 10, 2020 from https://www.zagreb-airport.hr/pos lovni/b2b-223/statistika/278

8. Galdini, R. (2007). Tourismand the city: Opportunity for regeneration. Tourismos: An International Multidisciplinary Journal of Tourism, 2(2), 95-111.

9. Horwath HTL. (2011). Strategija turističkog brendiranja grada Zagreba s planom promocije na međunarodnom tržištu [Branding strategy with an international promotion plan for the city of Zagreb]. Retrieved March 8, 2020 from https ://www.infozagreb.hr/kontakt/b2b/prezentacije-i-is trazivanja

10. Horwath HTL. (2016). Strateški i operativni marketinški plan TZGZ 2017.-2012. [Strategicand Operational Marketing Plan for TZGZ 2017-2012]. Retrieved March 8, 2020 from https://www.infozagreb.hr/documents/b2b/strates kioperativniplan.pdf

11. International Congress and Convention Association. (2019). ICCA Statistics Report Country \& City Ranking. Retrieved March 8, 2020 from http://www.iccaworld.org/dcps/doc.cfm?docid=2321

12. Ivanović, S., Alkier, R., \& Milojica, V. (2015). Development perspectives of city tourism offer of Rijeka. In M. Stanišić (Ed.). Singidunum International Tourism Conference-SITCON 2015 (pp. 58-64). Belgrade, Serbia: University Singidunum.

13. Ivanović, S., Alkier, R., Milojica, V. (2016a). Selective forms of tourismin the function of repositioning Croatian tourist product. In S. Vicić (Ed.). 6th International Biennial Congress HOTELPLAN 2016 Hospitalityand Tourism-InterdisciplinaryApproach (pp. 140-156). Belgrade, Serbia: The College of Hotel Management.

14. Ivanović, S., Mikinac, K., \& Milojica, V. (2016b). Importance of strategic managing in development a competitive event tourist offer. In H. M. Ribarić and D. S. Jurdana (Ed.). 23rd International Congress Tourism and Hospitality Industry 2016 Trends and Challenges (pp. 95-108). Opatija, Croatia: Faculty of Tourism and Hospitality Management in Opatija.

15. Kolb, M. B. (2006). Torism marketing for cities and towns. Oxford: Els evier Inc.

16. Law, C. M. (2002). Urban tourism: The visitor economy and the growth of large cities. London: Continium.

17. Official website of City of Zagreb (n.d.). Statisticki ljetopis grada Zagreba 2017-2019. [Statisticalyearbook of the cityofZagreb 2017-2019]. Retrieved March 15, 2020 from https ://www.zagreb.hr/statis ticki-ljetopis-grada-zagreba/1044

18. Official website of City of Zagreb. (2011). Razvojna strategija grada Zagreba [Development Strategy of City of Zagreb]. Retrieved March 16, 2020 from https://www.zagreb.hr/UserDocsImages/gu\%20za\%20strategijsko\%20planiranje/Razvoj na\%20strategija\%20Grada\%20Zagreba_SGGZ_18-17.pdf

19. Official website of City of Zagreb. (2017). Razvojna stategija grada Zagreba za razdoblje do 2020. godine [Development Strategy of the city of Zagreb for the period until 2020]. Retrieved March 6, 2020 from https://www.zagreb.hr/UserDocsImages/gu\%20za\%20strategijsko\%20planiranje/Razvoj na\%20strategija\%20Grada\%20Zagreba_SGGZ_18-17.pdf

20. Official website of City of Zagreb. (2020). Turističkipokazatelji i smeštajni kapaciteti. [Tourist indicators and accommodation capacities]. Retrieved March 15, 2020 from https://www.zagreb.hr/userdocsimages/arhiva/statistika/2019/turizam\%202019/Turizam $\% 20 \% 20 X I I . \% 202019 \% 20 . p d f$ 
21. Official website of Tourist Board of the city of Zagreb. (2018). Zagreb Visitor Survey $2017 / 18$ - Infographic Report. Retrieved March 11, 2020 from https://www.infozagreb.hr/documents/b2b/STRZagrebVisitorSurvey.pdf

22. Official website of Tourist Board of city of Zagreb. (2020a). Zagreb Time machine. Retrieved April 25, 2020 from https://www.infozagreb.hr/zagreb-time-machine$570 \mathrm{e} 0251 \mathrm{~b} 675 \mathrm{~d} \&$ lang=en

23. Official website of Tourist Board of city of Zagreb . (2020b). Retrieved May 6, 2020 from https://www.infozagreb.hr/

24. Pasquinelli, C., \& Bellini, N. (2017). Global context, policies and practices in urban tourism: An introduction. In N. Bellini and C. Pasquinelli (Eds.). Tourism in the city towards an integrative agenda on urban tourism (pp. 1-25). Cham, Switzerland: Springer International Publishing.

25. Podovac, M. (2019). Strategijske osnove razvoja turizma u gradovima Srbije. [Strategic bases of tourism development in Serbian cities] (Unpublis hed PhD thesis). Singidunum University, Belgrade, Serbia.

26. Smolčić-Jurdana, D., \& Magaš, D. (2006). City as a tourist destination - attributes, principles, goals. In V. Rajkovič (Ed.). 26th International Conference on Organizational Science Development Creative Organization (pp. 1714-1721). Portorož, Slovenia: University of Maribor, Faculty of Organizational Science.

27. Stanić Jovanović, S. (2016). Izletnički turistički proizvod opštine kao doprinos razvoju gradskog turizma Beograd: Studija s lučaja gradske opštine Surčin. [Excursion tourism product of municipality as a contribution to the development of urban touris $m$ in Belgrade: A case study of the city municipality of Surčin ]. Menadžmentu hotelijerstvu $i$ turizmu - Hotel and Tourism Management, 4(1), 31-42.

28. Štetić, S., Cvijanović, D., \& Šimičević, D. (2014). Posebni oblici turizma Dunavskog regiona Srbije [Special forms of tourism in the Danube region of Serbia]. Belgrade, Serbia: Institute of Agricultural Economics.

29. Tokarchuk, O., Gabriele, R., \& Maurer, O. (2016). Development of city tourism and well-being of urban residents: A case of German Magic Cities. Tourism Economics, 23(2) 343-359. https://doi.org/10.1177/1354816616656272 